\title{
A evolução dos cursos de Odontologia no Brasil
}

\author{
Alfredo Júlio Fernandes Neto*
}

* Ex-Presidente da ABENO

$\Delta$ regulamentação do exercício profissional da Odontologia data de 14/05/1856, com o Decreto $\mathrm{n}^{\mathrm{o}} 1.764$. O engajamento dos profissionais era feito pela concessão do título àqueles que recebiam um aprendizado informal, dentro de uma prática artesanal.

O ensino formal só teve início com o Decreto no 7.247 de 19/04/1879, que estabeleceu o curso de Cirurgia Dentária, anexo a faculdades de Medicina. Em 1882, foi criado na Bahia o primeiro curso, cujo currículo refletia o modo de produção social.

As matérias se dividiam em básicas e profissionais:

- Matérias Básicas

- Anatomia da Cabeça

- Histologia Dentária

- Fisiologia Dentária

- Patologia Dentária

E, ainda, Física Elementar e Química Mineral Elementar.

- Matérias Profissionais

- Terapêutica Dentária

- Medicina Operatória

- Cirurgia Dentária

Em 1884, foi retirada a matéria Medicina Operatória, sendo acrescentadas Prótese Dentária e Higiene da Boca. A duração dos cursos era de 2 (dois) anos.

Esse currículo permaneceu até o Decreto no 8.661, de 05/04/1911, quando foi introduzida a cadeira de Técnica Odontológica, com o ensino em manequins.

Nova alteração viria ter lugar com o Decreto no 3.830, de 29 de outubro de 1919, passando os cursos para 4 (quatro) anos de duração, dando ênfase a conhecimentos básicos em Biologia e Técnica Dentária.

O Decreto no 19.851 , de 11/04/1931, que estabeleceu a reforma do ensino superior no Brasil, fixou oficialmente o curso em 3 (três) anos de duração e exigia o curso ginasial na escola superior. O currículo passou a ter a seguinte estrutura:

$1^{\circ}$ ano: Anatomia, Fisiologia, Histologia e Micro- biologia, Metalurgia, Química Aplicada.

$2^{\circ}$ ano: Clínica Odontológica ( $1^{\underline{a}}$ cadeira), Higiene e Odontologia Geral, Prótese Dentária, Técnica Odontológica.

$3^{\circ}$ ano: Clínica Odontológica (2 ${ }^{\stackrel{a}{a}}$ cadeira), Patologia e Terapêutica Aplicadas, Prótese Buco-Facial, Ortodontia e Odontopediatria.

O Decreto no 20.179, de 6 de julho de 1931, destacou esse currículo como o padrão mínimo para o Brasil.

Em 1933, os cursos de Odontologia tornaram-se autônomos, ou seja, desligaram-se da tutela das escolas médicas, o que facultou a algumas escolas a criação de disciplinas além das obrigatórias.

Em 1961, com a Lei no 4.024, o Conselho Federal de Educação (CFE) passou a ter competência para fixar o currículo mínimo e a duração dos cursos superiores. Pelo Parecer 299/62, o CFE traçou o novo perfil do cirurgião-dentista (dentista geral, policlínico, destinado à coletividade) e estabeleceu o novo currículo em dois ciclos - básico e profissional -, aprovado em 16/11/1962.

- Ciclo Básico (2 anos):

- Anatomia

- Histologia - Embriologia

- Microbiologia

- Patologia Geral e Buco-Dental

- Farmacologia e Terapêutica

- Materiais Dentários

- Dentística Operatória

- Ciclo Profissionalizante (2 anos):

- Clínica Odontológica

- Cirurgia Odontológica

- Prótese Dentária

- Prótese Buco-Maxilo-Facial

- Ortodontia

- Odontopediatria

- Higiene e Odontologia Preventiva

- Odontologia Legal

Em $1^{\circ}$ de janeiro de 1971, surgia novo currículo, sem alterações substanciais, reorientando o ciclo básico com a Biologia, as Ciências Morfológicas, as 
Ciências Fisiológicas e a Patologia (Geral), ficando o ciclo profissional com a Patologia e Clínica Odontológica, Odontologia Social e Preventiva, a Odontopediatria e a Odontologia Restauradora.

Em 3 de setembro de 1982, o CFE estabeleceu o novo currículo mínimo, por meio da Resolução CFE no $04 / 82$.

\section{RESOLUÇÃO Nº 04/82 - CFE}

Fixa os mínimos de conteúdo (de 03/09/1982) e de duração do curso de Odontologia (de 16/09/1982).

O presidente do conselho federal de educação, na forma que dispõe o artigo 26 , da Lei $n^{\circ} 5.540$, de 28 de novembro de 1968 e, tendo em vista as conclusões do Parecer no $370 / 82$, homologado pelo Senhor Ministro da Educação e Cultura, resolve:

Art. $1^{\circ}$ - O currículo mínimo do curso de graduação em Odontologia compreende as seguintes matérias:

a. Matérias Básicas

- Ciências Morfológicas

- Ciências Fisiológicas

- Ciências Patológicas

- Ciências Sociais

b. Matérias Profissionalizantes

- Propedêutica Clínica

- Clínica Odontológica

- Clínica Odontopediátrica

- Odontologia Social

- Clínica Integrada

Art. $2^{\circ}$ - Nas Ciências Morfológicas serão ministrados conhecimentos de Genética, Evolução, Histologia e Embriologia, e Anatomia.

Art. $3^{\circ}$ - Nas Ciências Fisiológicas serão ministrados conhecimentos de Bioquímica, Fisiologia e Farmacologia.

Art. $4^{\circ}$ - Nas Ciências Patológicas serão ministrados conhecimentos de Patologia Geral, Microbiologia, Parasitologia e Imunologia.

Art. $5^{\circ}$ - Nas Ciências Sociais, estudar-se-ão fundamentos de Sociologia, Antropologia e Psicologia.

Art. $6^{\circ}$ - Na Propedêutica Clínica serão estudadas Patologia Bucal, Semiologia e Radiologia.

Art. $7^{0}$ - Na Clínica Odontológica estudar-se-ão Materiais Dentários, Dentística, Endodontia, Periodontia, Cirurgia, Traumatologia e Prótese, objetivando o tratamento e a restauração dos dentes e dos tecidos vizinhos.

Art. $8^{\circ}$ - Na Clínica Odontopediátrica estudar-se-ão os aspectos particulares da Patologia e da clínica da infância, bem como medidas preventivas ortodônticas.

Art. $9^{\circ}$ - Na Odontologia Social estudar-se-ão os aspectos sociais, deontológicos, legais e os de orientação profissional.

Art. $\mathbf{1 0}^{\circ}$ - Serão ministrados conhecimentos fundamentais de Escultura Dental e de Oclusão.

Art. $1^{\circ}$ - No Ciclo Profissionalizante deverão ser ministrados conhecimentos de: planejamento e administração de serviços de saúde comunitária, trabalho em equipe de saúde, Metodologia Científica, pessoal auxiliar, bem como técnicas e equipamentos odontológicos simplificados.

Art. $1^{\circ}$ - O ensino e treinamento dos alunos, em termos de necessidades globais dos pacientes, será realizado em clínica integrada com a duração mínima de um semestre letivo, sem prejuízo das atividades específicas utilizadas como recursos de ensino das diversas matérias profissionalizantes.

Art. $1^{\circ}$ - A prevenção constituir-se-á orientação do ensino enfocado nas diferentes disciplinas ou atividades.

Art. $1^{\circ}$ - O ensino deverá ser estruturado de tal forma que os programas instituam atividades do aluno junto ao paciente o mais precocemente possível, incrementando gradativamente as atividades de extensão.

Art. $1^{\circ}$ - As atividades extramurais serão desenvolvidas sob a forma de estágio supervisionado preferencialmente em Sistemas Públicos de Saúde.

Art. $\mathbf{1 6}^{\circ}$ - O curso de Odontologia terá a duração mínima de 3.600 (três mil e seiscentas) horas, integralizadas de 8 (oito) e máximo de 18 (dezoito) semestres letivos.

Art. $\mathbf{1 7}^{\circ}$ - As disciplinas Estudo de Problemas Brasileiros e Educação Física deverão integrar, obrigatoriamente, os currículos plenos, obedecendo as normas legais vigentes, não computada a carga horária das mesmas na duração mínima prevista nesta Resolução.

Art. $\mathbf{1 8}^{\circ}$ - A presente Resolução passará a vigorar a partir de 1983.

$$
\text { Lafaytte de Azevedo Pondé - Presidente. }
$$

Este currículo mínimo vigorou até a promulgação da Lei no 9.394, de 20 de dezembro de 1996 que estabelece as diretrizes e bases da educação nacional, a partir do que passará a vigorar as diretrizes curriculares, a serem aprovadas pelo Conselho Nacional de Educação - CNE. 